\title{
The FOMC in 1978
}

\author{
Richard G. Anderson and Charles S. Gascon
}

$\mathrm{T}$ he turbulent 1970s tested the resilience of Americans. A recession and stubborn inflation opened the decade; price and wage controls followed. OPEC's coming-of-age disrupted supplies and raised oil prices; an unpopular foreign war ended in retreat after a declaration of victory; and, for the first time in American history, both the president and vice president resigned under threat of impeachment. Against this backdrop, the Federal Open Market Committee (FOMC) struggled to temper a rising inflation trend while promoting full employment and maximum economic growth.

The year 1978 marks the transition between moderate consumer price inflation (CPI) during 1976 and 1977 (5.0 percent and 6.6 percent, respectively) and the more-than-12 percent rates during 1979 and 1980 : In 1978, the rate was 8.9 percent. The year also marks a shift in the social and political resolve to reduce inflation. At his final public appearance as Federal Reserve Chairman in January 1978, Arthur Burns expressed his frustration: "The need to fight inflation is widely recognized, but the will to do so is not yet strong enough. I have no doubt that the will...[for] unwinding the inflation will be forged someday." In December, reflecting on a year in which inflation had again been half higher than anticipated, Burns noted with approval that "the political leaders of both our major parties have finally recognized that inflation is the nation's number one problem" and that "even the moves of the Federal Reserve to bring down the rate of growth of the money supply, which not long ago caused consternation in some government circles, are now being accepted with grace and even gentle approbation." 2

Recently released FOMC transcripts for 1978 show that three topics dominated each meeting: actions to defend the falling foreign exchange value of the dollar, the increasing rate of inflation, and the risk of recession. At the year's first meeting, Chairman Burns and Vice Chairman Volcker agreed that domestic monetary policy was the key to the exchange rate deterioration. Commenting on attempts to support the dollar, Burns noted that "our intervention [in foreign exchange markets] has demonstrated the futility of the exercise." But Burns was reluctant to tighten domestic monetary policy by increasing interest rates. Throughout his career, Burns argued that current economic conditions were driven largely by the public's expectations of the future pace of activity. ${ }^{3}$ Sharp interest rate increases risked derailing the modest expansion of 1976-77, during which business investment already had been weak. Hesitancy continued after G. William Miller became Chairman in late March. Most FOMC members appeared to believe inflation could be slowed only with policies that also slowed economic growth and thereby increased the risk of recession. ${ }^{4}$ Notable exceptions were Reserve Bank presidents Roos of St. Louis and Willes of

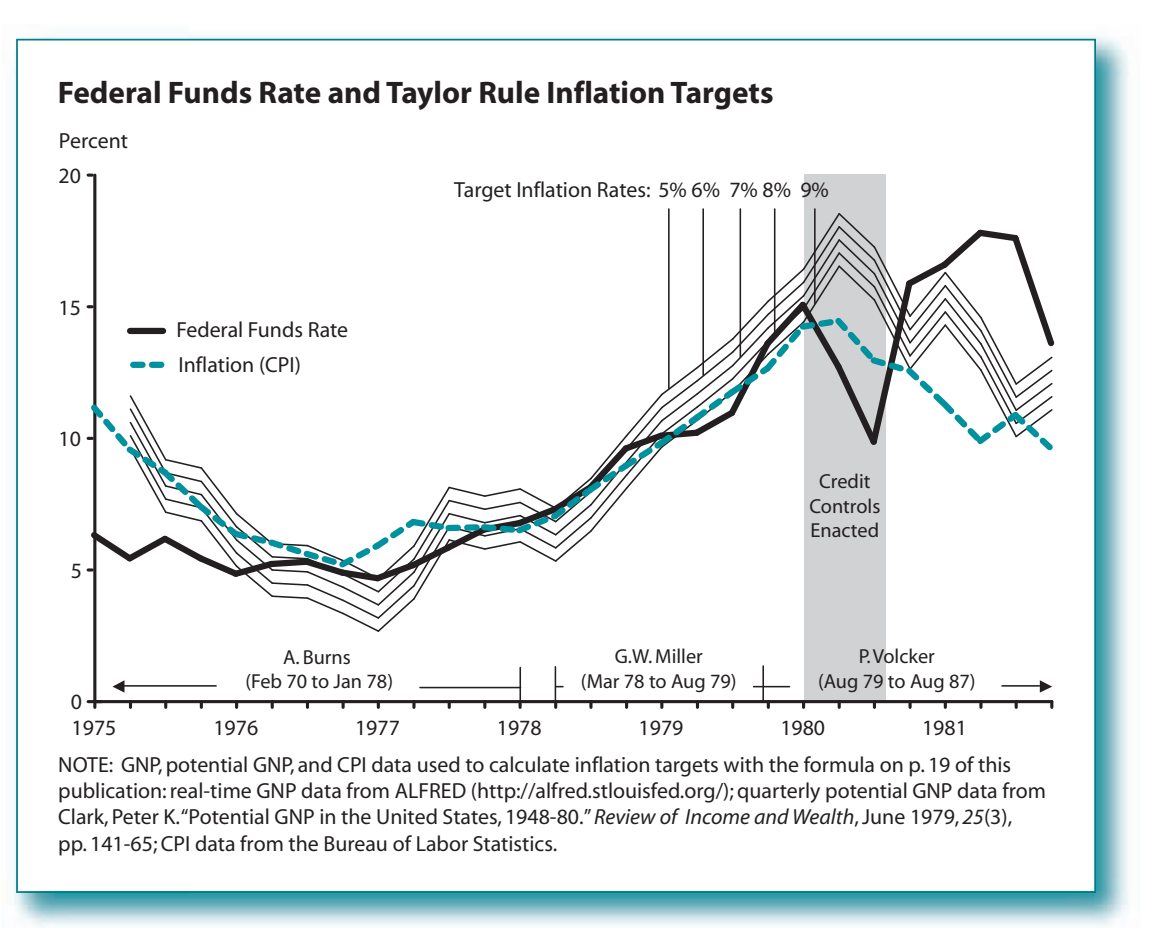

Minneapolis, who argued uncertainty about future monetary policy (and, hence, inflation) was the important factor threatening the pace of economic activity-not "tight" monetary policy.

The FOMC's actions during 1978 may be seen as attempts to stabilize inflation without undermining business confidence: They increased their federal funds rate target from $6^{3 / 4}$ percent at the January 17 meeting to 10 percent at the December 19 meeting. The failure of these actions to dampen inflation is shown in the chart, which suggests the FOMC's rate targets were consistent with the realized 7 to 9 percent inflation rate incurred by the economy.

\begin{abstract}
1 http://fraser.stlouisfed.org/historicaldocs/statements/download/27692/ Burns_19780130.pdf.

2 http://www.aei.org/publications/pubID.15232,filter.all/pub_detail.asp.

${ }^{3}$ Hetzel, Robert. "Arthur Burns and Inflation." Federal Reserve Bank of Richmond Economic Quarterly, Winter 1998, 84(1), pp. 21-44.

4 This belief was not limited to FOMC members. In reflections on 1978-79, Ted Truman, at the time director of the Division of International Finance at the Federal Reserve Board, recalls Lyle Gramley, a member of the Council of Economic Advisers, arguing at a July 1978 OECD meeting that one more 25-basis-point increase in the federal funds rate target would push the economy into recession: Truman, Edwin. "Reflections." Federal Reserve Bank of St. Louis Review, March/ April 2005, 87(2, Part 2), pp. 353-57.
\end{abstract}

Views expressed do not necessarily reflect official positions of the Federal Reserve System. 